\title{
Nitrogen distribution in four grain legumes
}

\author{
S. AYAZ, B. A. McKENZIE, G. D. HILL* And D. L. McNEIL† \\ Plant Sciences Group, Soil, Plant and Ecological Sciences Division, PO Box 84, Lincoln University, New Zealand
}

(Revised MS received 8 July 2004)

\begin{abstract}
SUMMARY
The partitioning of above ground nitrogen $(\mathrm{N})$ in chickpea (Cicer arietinum), lentil (Lens culinaris), lupin (Lupinus angustifolius) and pea (Pisum sativum) at crop maturity was investigated. The plants were grown at different plant populations and sowing depths in 1998/99 and 1999/2000 in Canterbury, New Zealand. In all four legumes the $\mathrm{N}$ concentration was highest in seed $(29-36 \mathrm{mg} / \mathrm{g}$ $\mathrm{N}$ ) followed by senescent leaves. The lowest $\mathrm{N}$ concentration was in stems. Lupin had the highest seed $\mathrm{N}$ yield at 16.82 and $19.29 \mathrm{~g} / \mathrm{m}^{2}$ followed by chickpea at 10.26 and $13.10 \mathrm{~g} / \mathrm{m}^{2}$, in $1998 / 99$ and $1999 /$ 2000 , respectively. Lentil had the lowest $\mathrm{N}$ concentrations and yield. The distribution of $\mathrm{N}$ to all legume plant parts increased as population increased up to twice the optimum and 400 plants $/ \mathrm{m}^{2}$ in 1998/99 and 1999/2000, respectively. Over all plant populations, the nitrogen harvest index (NHI) was stable in each of the four species across the two seasons. However, the NHI changed with changes in plant population and sowing depth. The $\mathrm{N}$ accumulation efficiency $\left(E_{\mathrm{N}}\right)$ was highest in lentil at 0.024 and $0.027 \mathrm{~g} \mathrm{~N} / \mathrm{g} \mathrm{DM}$ and lowest in chickpea at 0.018 and $0.021 \mathrm{~g} \mathrm{~N} / \mathrm{g} \mathrm{DM}$ in 1998/99 and $1999 / 2000$, respectively. The NHI and the crop harvest index (CHI) were correlated and both were strongly associated with seed yield. Thus, NHI might be useful as a selection criterion to improve seed yield in grain legumes.
\end{abstract}

\section{INTRODUCTION}

The performance of various legume species in terms of their biomass production and nitrogen $(\mathrm{N})$ yield varies considerably among legume species and years (Schulz et al. 1999). In the field, $\mathrm{N}$ accumulation in grain legumes results from symbiotic $\mathrm{N}$ fixation and from $\mathrm{N}$ uptake from both soil and fertilizer (Chapman \& Muchow 1985). Nitrogen concentration varies among different plant parts (Spaeth \& Sinclair 1983). In the seed, leaves and stems of soybean (Glycine max), N concentrations were 42.3, 9.4 and $4.7 \mathrm{mg} / \mathrm{g}$ respectively (Streeter 1978). At harvest maturity, $\mathrm{N}$ concentrations in stems of peanut (Arachis hypogaea), soybean and pigeon pea (Cajanus cajan) were between 10 and $20 \mathrm{mg} / \mathrm{g}$, while in the seed the $\mathrm{N}$ concentrations were 50,68 and $35 \mathrm{mg} / \mathrm{g}$, respectively (de Vries et al. 1989).

Data on the $\mathrm{N}$ concentration of senescent legume leaves are scarce. However, in Australia, Bushby \& Lawn (1992) reported that the $\mathrm{N}$ concentration in senescent leaves of three mungbean (Vigna radiata)

* To whom all correspondence should be addressed. Email: hill1@lincoln.ac.nz

$\uparrow$ Present address: DNRE, Victorian Institute for Dryland Agriculture, PMB 260, Horsham, Victoria 3401, Australia. genotypes was $11 \cdot 3,9.4$ and $14.3 \mathrm{mg} / \mathrm{g}$. This represented $4 \cdot 4,12.9$ and $9 \cdot 6 \%$ of total plant $\mathrm{N}$ in the three genotypes, respectively. Muchow et al. (1993a) reported that the amount of seed $\mathrm{N}$ in soybean at maturity was greater than in mungbean and cowpea (Vigna unguiculata), and this was associated with a higher nitrogen harvest index (NHI). Muchow et al. (1993a) also reported that soybean, at maturity, had a higher $\mathrm{N}$ accumulation efficiency $\left(E_{\mathrm{N}} ; 0.035 \mathrm{~g} / \mathrm{g}\right)$ than mungbean $(0.025 \mathrm{~g} / \mathrm{g})$ and cowpea $(0 \cdot 023 \mathrm{~g} / \mathrm{g})$. Newton \& Hill (1981) compared the NHIs of Vicia faba cultivars Daffa and Maris Bead, and concluded that Maris Bead consistently partitioned more $\mathrm{N}$ to seed than Daffa over plant populations and seasons. The NHI values of mungbean genotypes ranged from 0.65 to 0.90 (Bushby \& Lawn 1992).

In the present work four grain legumes were grown at different plant populations and sowing depths to investigate their nitrogen distribution at final harvest. This was done to assess whether:

(1) Species differences in NHI were consistent over plant populations, sowing depths and growing seasons.

(2) The NHI of legumes was associated with their yield and the CHI. 
(3) The NHI was sufficiently consistent to be a viable trait for use in plant selection.

\section{MATERIALS AND METHODS}

\section{Site and soil characteristics}

The experiments were sown at the Horticultural Research Area in 1998/99 and at the Henley Research Farm in 1999/2000. Both sites are at Lincoln University, Canterbury, New Zealand (latitude $43^{\circ} 39^{\prime} \mathrm{S}$, longitude $\left.172^{\circ} 28^{\prime} \mathrm{E}\right)$. The soil is a Wakanui silt loam soil (Hewitt 1992). A Chinese cabbage (Brassica pekinensis) crop had been grown in the previous season to the 1998/99 experiment, and the Henley site, used in 1999/2000, was previously in perennial ryegrass (Lolium perenne). A Ministry of Agriculture and Fisheries (MAF) soil quick test was done in each season to determine soil available nutrient levels (Table 1).

\section{Experimental design}

In 1998/99 the design was a split-plot randomized block. The four grain legume species chickpea (Cicer arietinum), lentil (Lens culinaris), narrow-leafed lupin (Lupinus angustifolius) and field pea (Pisum sativum) were main plots. Subplots were four plant populations, one-tenth of the optimum population, the optimum population, twice the optimum population and four times the optimum population. Optimum plant populations (determined from recommended commercial sowing rates) were taken as 50 plants $/ \mathrm{m}^{2}$ for chickpea, 150 plants $/ \mathrm{m}^{2}$ for lentil, 100 plants $/ \mathrm{m}^{2}$ for narrow-leafed lupin and 100 plants $/ \mathrm{m}^{2}$ for field pea. There were three replicates. The trial was sown on 30 October 1998. Seed was sown at $4-5 \mathrm{~cm}$ depth using a tractor-driven cone seeder in rows $15 \mathrm{~cm}$ apart.

In 1999/2000 the design was a split-split plot design. The trial had the same four legumes as main plots. Subplots were three plant populations: 10, 100 and 400 plants $/ \mathrm{m}^{2}$. Three sowing depths $(2,5$ and $10 \mathrm{~cm})$ were sub-subplots. There were three replicates. The plots were hand sown, one replicate per 2 days between 19 and 24 October 1999 in equidistant arrangements. Sowing was on the square at $31.5 \times 31.5 \mathrm{~cm}$, $10 \times 10 \mathrm{~cm}$ and $5 \times 5 \mathrm{~cm}$.

Full details of crop husbandry in the 2 years are contained in Ayaz (2001).

\section{Sampling and measurements}

At maturity when $95 \%$ of all plants were brown, five plants were taken from the central rows of each sub or sub-subplot as the final harvest. The plants were cut to ground level and separated into seed and straw (stem + petioles + pod walls). Senesced leaves were collected from the ground of the harvested area and
Table 1. Ministry of Agriculture and Fisheries soil quick test for $0-30 \mathrm{~cm}$ depth for the Horticultural Research Area (1998/99) and the Henley Research Farm (1999/2000) of Lincoln University, Canterbury. $\mathrm{Ca}, \mathrm{K}, \mathrm{P}, \mathrm{Mg}$, $\mathrm{Na}$ and $\mathrm{S}$ and $\mathrm{NH}_{4}^{+}, \mathrm{NO}_{3}^{-}$are expressed as $\mu \mathrm{g} / \mathrm{g}$ soil, and total $N(T N)$ and $C$ as $\mathrm{mg} / \mathrm{g}$

\begin{tabular}{cccccccccccc}
\hline Season & $\mathrm{pH}$ & $\mathrm{Ca}$ & $\mathrm{K}$ & $\mathrm{P}$ & $\mathrm{Mg}$ & $\mathrm{Na}$ & $\mathrm{S}$ & $\mathrm{C}$ & $\mathrm{NH}_{4}^{+}$ & $\mathrm{NO}_{3}^{-}$ & $\mathrm{TN}$ \\
\hline $\begin{array}{r}1998 / \\
1999\end{array}$ & $5 \cdot 4$ & 7 & 8 & 27 & 16 & 5 & 9 & 24 & - & 1 & 2 \\
$1999 /$ & $5 \cdot 8$ & 10 & 9 & 12 & 28 & 8 & 9 & - & 5 & $<1$ & 3 \\
2000 & & & & & & & & & & & \\
\hline \hline
\end{tabular}
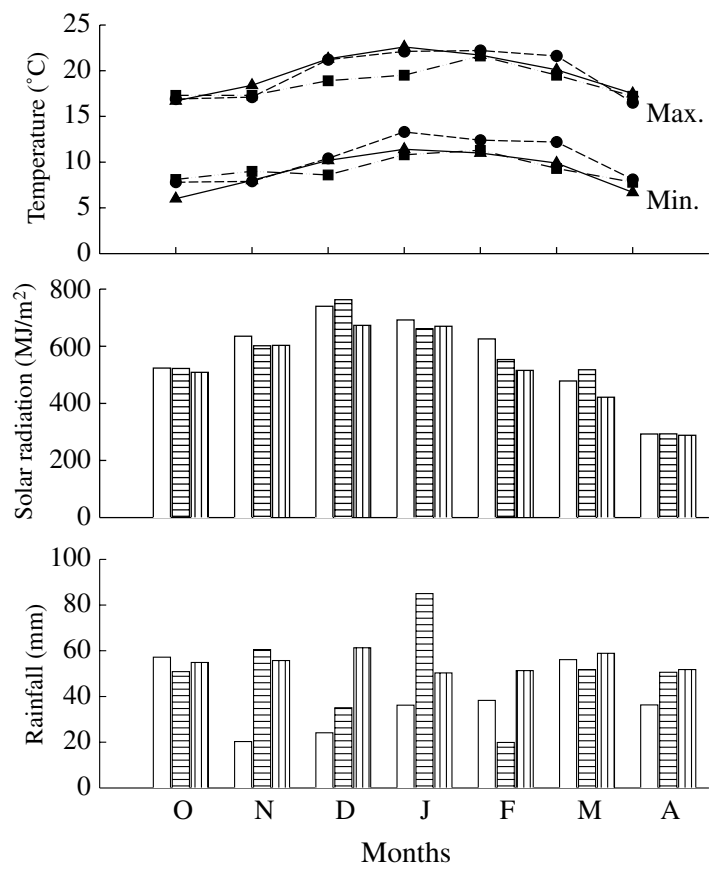

Fig. 1. Climate data for $1998 / 99(\square$, ○) and 1999/2000 (目, 口) growing seasons and long-term means (四, $\mathbf{\Delta})$ for Lincoln University, Canterbury, New Zealand. Long-term means for rainfall and temperature 1944-99 and for solar radiation 1975-99.

were bagged separately. All plant material was chopped and oven dried at $70{ }^{\circ} \mathrm{C}$ for $48 \mathrm{~h}$ in a forced draught oven. Samples were ground in a Cyclotech mill to pass through a $0.5 \mathrm{~mm}$ screen for $\mathrm{N}$ analysis. Senescent leaves, straw and seed samples were analysed for their $\mathrm{N}$ concentration by the Kjeldahl method.

The nitrogen harvest index (NHI) was calculated as the amount of $\mathrm{N}$ in seed as a proportion of total aboveground plant $\mathrm{N}$. The $\mathrm{N}$ accumulation efficiency $\left(E_{\mathrm{N}}\right)$ was determined for each legume species as the ratio between net aboveground $\mathrm{N}$ and the net total 
Table 2. The effect of legume species and plant population on the $N$ concentration of seed, straw (stem + petioles + pod walls), and senesced leaves at final harvest in Canterbury, 1998/1999

\begin{tabular}{lccc}
\hline \hline & \multicolumn{3}{c}{$\mathrm{N}$ at final harvest $(\mathrm{mg} / \mathrm{g} \mathrm{DM})$} \\
\cline { 2 - 4 } & & \multicolumn{2}{c}{$\begin{array}{c}\text { Senesced } \\
\text { leaf }\end{array}$} \\
Treatments & Seed & Straw & \\
Species (S) & & & \\
Chickpea & $26 \cdot 6$ & $5 \cdot 5$ & $18 \cdot 3$ \\
Lentil & $30 \cdot 4$ & $8 \cdot 5$ & $17 \cdot 5$ \\
Lupin & $43 \cdot 2$ & $4 \cdot 3$ & $16 \cdot 0$ \\
Pea & $29 \cdot 0$ & $14 \cdot 2$ & $28 \cdot 6$ \\
S.E. & $1 \cdot 27$ & $0 \cdot 97$ & $1 \cdot 44$ \\
Population (P) & & & \\
$0 \cdot 1 \times$ optimum & $30 \cdot 5$ & $8 \cdot 3$ & $19 \cdot 7$ \\
$1 \cdot 0 \times$ optimum & $30 \cdot 2$ & $8 \cdot 4$ & $19 \cdot 7$ \\
$2 \cdot 0 \times$ optimum & $35 \cdot 3$ & $8 \cdot 0$ & $21 \cdot 0$ \\
$4 \cdot 0 \times$ optimum & $33 \cdot 3$ & $7 \cdot 7$ & $20 \cdot 0$ \\
S.E. & $1 \cdot 42$ & $0 \cdot 57$ & $0 \cdot 91$ \\
CV $\%$ & $15 \cdot 2$ & $24 \cdot 2$ & $15 \cdot 7$ \\
Sign. interactions & $\mathrm{ns}$ & $\mathrm{ns}$ & $\mathrm{ns}$ \\
\hline \hline
\end{tabular}

dry matter (TDM) at final harvest (Chapman \& Muchow 1985; Muchow et al. 1993 b).

\section{Climate}

From October 1998 to April 1999, the weather was dry and the rainfall was about $40 \%$ less than the long-term average (Fig. 1). The mean temperature and solar radiation were higher than the long-term average by $5 \%$ and $7 \%$, respectively, from January to March 1999. In the second year the rainfall was about $90 \%$ of the long-term average $(385 \mathrm{~mm})$. The mean monthly maximum temperatures in December 1999 and January 2000 were lower at 18.9 and $19.5^{\circ} \mathrm{C}$, respectively, than the long-term average values of 21.3 and $22.6{ }^{\circ} \mathrm{C}$, respectively (Fig. 1). Solar radiation from December 1999 to March 2000 was about $10 \%$ higher than the long-term mean.

\section{Statistical analysis}

All variates were analysed using analysis of variance. The statistical package used was Genstat. Standard errors (s.E.), coefficients of variation ( $\mathrm{CV}$ as a \%) and the correlation coefficient $(r)$ were also calculated.

\section{RESULTS}

\section{Nitrogen concentration and its partitioning}

The $\mathrm{N}$ concentration of seed, straw and senesced leaves of the four legumes species is shown in Tables 2 and 3. The $\mathrm{N}$ concentration of seed, straw and
Table 3. The effect of legume species, plant population and sowing depth on the $N$ concentration in seed, straw (stem + petioles + pod walls), and senesced leaves at final harvest in Canterbury, 1999/2000

\begin{tabular}{lccc}
\hline \hline & \multicolumn{3}{c}{ N at final harvest $(\mathrm{mg} / \mathrm{g} \mathrm{DM})$} \\
\cline { 2 - 4 } & & \multicolumn{2}{c}{$\begin{array}{c}\text { Senesced } \\
\text { leaf }\end{array}$} \\
Treatments & Seed & Straw & \\
Species (S) & & & \\
Chickpea & $29 \cdot 4$ & $8 \cdot 1$ & $20 \cdot 3$ \\
Lentil & $34 \cdot 5$ & $14 \cdot 3$ & $14 \cdot 6$ \\
Lupin & $36 \cdot 2$ & $7 \cdot 9$ & $7 \cdot 5$ \\
Pea & $31 \cdot 7$ & $17 \cdot 3$ & $23 \cdot 3$ \\
S.E. & $0 \cdot 19$ & $0 \cdot 17$ & $0 \cdot 29$ \\
Population $(\mathrm{P})$ & & & \\
10 plants $/ \mathrm{m}^{2}$ & $33 \cdot 5$ & $11 \cdot 6$ & $16 \cdot 1$ \\
100 plants $/ \mathrm{m}^{2}$ & $32 \cdot 0$ & $12 \cdot 0$ & $16 \cdot 5$ \\
400 plants $/ \mathrm{m}^{2}$ & $33 \cdot 5$ & $12 \cdot 1$ & $16 \cdot 7$ \\
S.E. & $3 \cdot 0$ & $0 \cdot 23$ & $0 \cdot 17$ \\
Depth (D) & & & \\
$2 \mathrm{~cm}$ & $32 \cdot 5$ & $11 \cdot 9$ & $16 \cdot 6$ \\
$5 \mathrm{~cm}$ & $32 \cdot 9$ & $12 \cdot 1$ & $16 \cdot 6$ \\
$10 \mathrm{~cm}$ & $33 \cdot 4$ & $11 \cdot 7$ & $16 \cdot 0$ \\
S.E. & $0 \cdot 11$ & $0 \cdot 22$ & $0 \cdot 20$ \\
CV \% & $1 \cdot 9$ & $11 \cdot 3$ & $7 \cdot 4$ \\
Sign. interactions & $\mathrm{ns}$ & $\mathrm{ns}$ & $\mathrm{ns}$ \\
\hline \hline
\end{tabular}

senesced leaves varied significantly $(P<0 \cdot 001)$ among the legume species. However, there were no significant interactions in either season.

In all four legumes, the seed $\mathrm{N}$ concentration was highest followed by the $\mathrm{N}$ level in senesced leaves. The lowest $\mathrm{N}$ concentration was in the straw. Narrowleafed lupin had the highest seed $\mathrm{N}$ concentration in both 1998/99 and 1999/2000. Chickpea seed had the lowest $\mathrm{N}$ concentration in both years. Narrow-leafed lupin straw had a lower $\mathrm{N}$ concentration than straw from the other three species. The $\mathrm{N}$ concentration in field pea straw was the highest compared with the other species in both years. The $\mathrm{N}$ concentration of the senesced leaves varied from $16 \mathrm{mg} / \mathrm{g}$ in narrowleafed lupin to $28.6 \mathrm{mg} / \mathrm{g}$ in field pea in 1998/99 and from $7.5 \mathrm{mg} / \mathrm{g}$ in narrow-leafed lupin to $23.3 \mathrm{mg} / \mathrm{g}$ in field pea in 1999/2000. In the second year, plants sown at $10 \mathrm{~cm}$ depth had higher seed $\mathrm{N}$ concentrations than plants from the shallower sowings.

\section{Nitrogen yield and partitioning}

The $\mathrm{N}$ yield of seed, straw and senesced leaves varied significantly $(P<0 \cdot 001)$ among the legumes (Tables 4 and 5). Narrow-leafed lupin produced the most seed $\mathrm{N}$ in both years, followed by chickpea. Lentil produced the lowest seed $\mathrm{N}$ in both years.

In 1998/99 the amount of $\mathrm{N}$ partitioned to straw at final harvest was not consistent among species 
Table 4. The effect of legume species and plant population on yield of $N$ in seed, straw (stem + petioles + pod walls), and senesced leaves, $N$ accumulation efficiency $\left(E_{N}\right)$ and nitrogen harvest index $(N H I)$ at final harvest in Canterbury, 1998/1999

\begin{tabular}{|c|c|c|c|c|c|c|}
\hline \multirow[b]{2}{*}{ Treatments } & \multicolumn{4}{|c|}{$\mathrm{N}$ yield at final harvest $\left(\mathrm{g} / \mathrm{m}^{2}\right)$} & \multirow[b]{2}{*}{$E_{\mathrm{N}}(\mathrm{g} / \mathrm{g})$} & \multirow[b]{2}{*}{ NHI } \\
\hline & Seed & Straw & Senesced leaf & Total & & \\
\hline \multicolumn{7}{|l|}{ Species (S) } \\
\hline Chickpea & $10 \cdot 26$ & $1 \cdot 29$ & $1 \cdot 56$ & $13 \cdot 11$ & $0 \cdot 018$ & 0.75 \\
\hline Lentil & $7 \cdot 58$ & $1 \cdot 01$ & $0 \cdot 99$ & $9 \cdot 57$ & $0 \cdot 025$ & 0.78 \\
\hline Lupin & $16 \cdot 82$ & $1 \cdot 72$ & $1 \cdot 46$ & $20 \cdot 02$ & $0 \cdot 022$ & $0 \cdot 84$ \\
\hline Pea & $8 \cdot 46$ & $2 \cdot 46$ & $2 \cdot 04$ & $12 \cdot 96$ & $0 \cdot 024$ & 0.64 \\
\hline S.E. & $0 \cdot 529$ & $0 \cdot 174$ & $0 \cdot 235$ & $0 \cdot 714$ & $0 \cdot 0011$ & $0 \cdot 017$ \\
\hline \multicolumn{7}{|l|}{ Population (P) } \\
\hline $0.1 \times$ optimum & $5 \cdot 72$ & $1 \cdot 31$ & 0.92 & $7 \cdot 95$ & $0 \cdot 019$ & 0.68 \\
\hline $1.0 \times$ optimum & $10 \cdot 31$ & $1 \cdot 73$ & $1 \cdot 57$ & $13 \cdot 61$ & $0 \cdot 021$ & $0 \cdot 75$ \\
\hline $2 \cdot 0 \times$ optimum & $14 \cdot 13$ & 1.78 & 1.87 & $17 \cdot 78$ & $0 \cdot 024$ & $0 \cdot 80$ \\
\hline $4.0 \times$ optimum & $12 \cdot 96$ & $1 \cdot 66$ & $1 \cdot 70$ & $16 \cdot 32$ & $0 \cdot 023$ & 0.78 \\
\hline S.E. & $0 \cdot 580$ & $0 \cdot 122$ & $0 \cdot 096$ & $0 \cdot 651$ & $0 \cdot 001$ & $0 \cdot 009$ \\
\hline $\mathrm{CV} \%$ & $18 \cdot 6$ & $26 \cdot 1$ & $21 \cdot 9$ & $16 \cdot 2$ & $13 \cdot 6$ & $4 \cdot 5$ \\
\hline Sign. interactions & $\mathrm{ns}$ & $\begin{array}{l}\mathrm{S} \times \mathrm{P} \\
(P<0 \cdot 05)\end{array}$ & ns & ns & ns & ns \\
\hline
\end{tabular}

Table 5. The effect of legume species, plant population and sowing depth on yield of $N$ in seed, straw (stem + petioles + pod walls), and senesced leaves, $N$ accumulation efficiency $\left(E_{N}\right)$ and nitrogen harvest index $(N H I)$ at final harvest in Canterbury, 1999/2000

\begin{tabular}{|c|c|c|c|c|c|c|}
\hline \multirow[b]{2}{*}{ Treatments } & \multicolumn{4}{|c|}{$\mathrm{N}$ yield at final harvest $\left(\mathrm{g} / \mathrm{m}^{2}\right)$} & \multirow[b]{2}{*}{$E_{\mathrm{N}}(\mathrm{g} / \mathrm{g})$} & \multirow[b]{2}{*}{ NHI } \\
\hline & Seed & Straw & Senesced leaf & Total & & \\
\hline \multicolumn{7}{|l|}{ Species (S) } \\
\hline Chickpea & $13 \cdot 10$ & $2 \cdot 01$ & 1.90 & $17 \cdot 00$ & $0 \cdot 021$ & $0 \cdot 75$ \\
\hline Lentil & $9 \cdot 76$ & $1 \cdot 66$ & $0 \cdot 87$ & $12 \cdot 29$ & $0 \cdot 027$ & $0 \cdot 78$ \\
\hline Lupin & $19 \cdot 29$ & $2 \cdot 47$ & $1 \cdot 02$ & $22 \cdot 78$ & $0 \cdot 023$ & $0 \cdot 84$ \\
\hline Pea & $11 \cdot 44$ & $3 \cdot 21$ & $1 \cdot 39$ & $16 \cdot 03$ & 0.026 & 0.69 \\
\hline S.E. & $0 \cdot 409$ & $0 \cdot 165$ & $0 \cdot 108$ & $0 \cdot 354$ & $0 \cdot 0003$ & $0 \cdot 010$ \\
\hline \multicolumn{7}{|l|}{ Population (P) } \\
\hline 10 plants $/ \mathrm{m}^{2}$ & $7 \cdot 80$ & $1 \cdot 87$ & $0 \cdot 80$ & $10 \cdot 47$ & 0.023 & $0 \cdot 72$ \\
\hline 100 plants $/ \mathrm{m}^{2}$ & $13 \cdot 49$ & $2 \cdot 54$ & $1 \cdot 38$ & $17 \cdot 40$ & 0.024 & $0 \cdot 77$ \\
\hline 400 plants $/ \mathrm{m}^{2}$ & $18 \cdot 91$ & $2 \cdot 60$ & $1 \cdot 70$ & $23 \cdot 21$ & 0.026 & $0 \cdot 80$ \\
\hline S.E. & $1 \cdot 18$ & $0 \cdot 061$ & $0 \cdot 036$ & $1 \cdot 17$ & $0 \cdot 0002$ & $0 \cdot 017$ \\
\hline \multicolumn{7}{|l|}{ Depth (D) } \\
\hline $2 \mathrm{~cm}$ & $12 \cdot 78$ & $2 \cdot 34$ & $1 \cdot 28$ & $16 \cdot 40$ & $0 \cdot 024$ & $0 \cdot 75$ \\
\hline $5 \mathrm{~cm}$ & $13 \cdot 43$ & $2 \cdot 40$ & $1 \cdot 32$ & $17 \cdot 14$ & 0.024 & $0 \cdot 76$ \\
\hline $10 \mathrm{~cm}$ & $13 \cdot 98$ & $2 \cdot 27$ & $1 \cdot 28$ & $17 \cdot 53$ & 0.025 & $0 \cdot 78$ \\
\hline S.E. & $0 \cdot 089$ & $0 \cdot 046$ & $0 \cdot 019$ & $0 \cdot 102$ & $0 \cdot 0002$ & $0 \cdot 002$ \\
\hline $\mathrm{CV} \%$ & $4 \cdot 0$ & $11 \cdot 7$ & $8 \cdot 7$ & $3 \cdot 6$ & $3 \cdot 8$ & $2 \cdot 0$ \\
\hline Sign. interactions & ns & $\begin{array}{l}\mathrm{S} \times \mathrm{P} \\
(P<0 \cdot 001)\end{array}$ & $\begin{array}{l}\mathrm{S} \times \mathrm{P} \\
(P<0.001)\end{array}$ & ns & ns & $\mathrm{ns}$ \\
\hline
\end{tabular}

(Fig. 2a). The straw $\mathrm{N}$ yield in chickpea decreased as plant population increased. In contrast, in narrowleafed lupin straw $\mathrm{N}$ yield increased as plant population increased up to four times the optimum. The other two species had variable responses to changed plant population.

In $1999 / 2000$, the $\mathbf{N}$ yields from straw in field pea and lentil increased from one-tenth the optimum to 

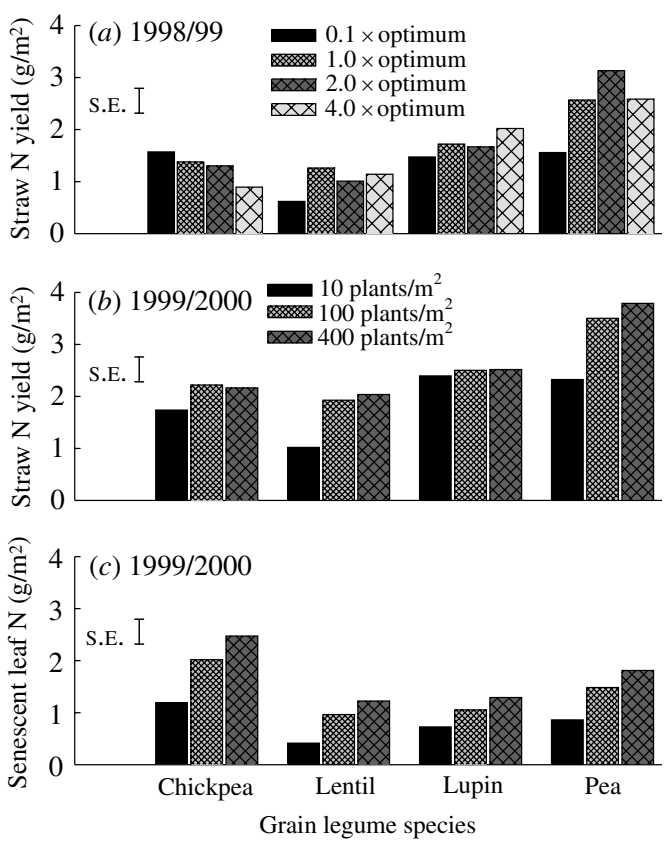

Fig. 2. Straw nitrogen yield in 1998/99 (a), and straw $(b)$ and senesced leaf $N$ yields in 1999/2000 (c) of four grain legumes sown at different plant populations in Canterbury.

four times the optimum but was unchanged in narrow-leafed lupin. Straw N increased in chickpea up to twice the optimum population and then plateaued at the highest population (Fig. $2 b$ ). In the second year, all four species had a marked increase in the $\mathrm{N}$ yield from senesced leaves with increased plant population (Fig. 2c).

All four species showed marked variation in their total $\mathrm{N}$ yield at final harvest (Tables 4 and 5). In both seasons, narrow-leafed lupin gave the highest amount of total $\mathrm{N}$. The lowest total $\mathrm{N}$ yield was from lentil in both years. Increasing sowing depth from 2 to $10 \mathrm{~cm}$ increased total $\mathrm{N}$ yields slightly (Table 5). There were no significant interactions. Overall, crops in the second season contained about $20 \%$ more $\mathrm{N}$ than in the first season.

\section{Nitrogen accumulation efficiency}

The calculated $\mathrm{N}$ accumulation efficiency $\left(E_{\mathrm{N}}\right)$ at final harvest is shown in Tables 4 and 5 . The $E_{\mathrm{N}}$ was highest in lentil and was lowest in chickpea. In the first season, as plant population increased $E_{\mathrm{N}}$ increased by $20 \%$ (Table 4). However, in the second year there was only a $13 \%$ increase in $E_{\mathrm{N}}$ as plant population increased (Table 4). Again there were no significant interactions. However, increased sowing depth slightly increased $E_{\mathrm{N}}$ from 0.024 to $0.025 \mathrm{~g} \mathrm{~N} / \mathrm{g} \mathrm{DM}$.
Table 6. Senesced leaf DM production $\left(\mathrm{g} / \mathrm{m}^{2}\right)$ of the four legume species at final harvest in Canterbury, $1998 / 99$ and $1999 / 2000$

\begin{tabular}{|c|c|c|c|}
\hline $1998 / 99$ & & \multicolumn{2}{|c|}{$1999 / 2000$} \\
\hline Species (S) & & Species & \\
\hline Chickpea & 90 & Chickpea & 103 \\
\hline Lentil & 59 & Lentil & 68 \\
\hline Lupin & 100 & Lupin & 149 \\
\hline Pea & 76 & Pea & 75 \\
\hline S.E. & $8 \cdot 3$ & S.E. & $12 \cdot 5$ \\
\hline $\begin{array}{l}\text { Population }(\mathrm{P}) \\
0 \cdot 1 \times \text { optimum } \\
1 \cdot 0 \times \text { optimum } \\
2 \cdot 0 \times \text { optimum } \\
4 \cdot 0 \times \text { optimum }\end{array}$ & $\begin{array}{r}29 \\
85 \\
101 \\
100\end{array}$ & $\begin{array}{l}\text { Population }(\mathrm{P}) \\
10 \text { plants } / \mathrm{m}^{2} \\
100 \text { plants } / \mathrm{m}^{2} \\
400 \text { plants } / \mathrm{m}^{2}\end{array}$ & $\begin{array}{r}58 \\
101 \\
138\end{array}$ \\
\hline S.E. & $1 \cdot 6$ & $\begin{array}{l}\text { S.E. } \\
\text { Depth (D) } \\
2 \mathrm{~cm} \\
5 \mathrm{~cm} \\
\quad 10 \mathrm{~cm} \\
\text { S.E. }\end{array}$ & $\begin{array}{c}1 \cdot 4 \\
97 \\
98 \\
101 \\
0 \cdot 23\end{array}$ \\
\hline $\begin{array}{l}\mathrm{CV} \% \\
\text { Sign. interactions }\end{array}$ & $\begin{array}{l}\quad 7 \cdot 3 \\
\mathrm{~S} \times \mathrm{P} \\
(P<0 \cdot 01)\end{array}$ & $\mathrm{CV} \%$ & $\begin{array}{l}1.6 \\
\mathrm{~S} \times \mathrm{P} \\
(P<0 \cdot 01)\end{array}$ \\
\hline
\end{tabular}

\section{Nitrogen harvest index}

In the four legume species, the NHI varied from $0 \cdot 64-0 \cdot 84$ in 1998/99 and from 0.69-0.84 in 1999/2000 (Tables 4 and 5). Narrow-leafed lupin had the highest NHI at 0.84 in both seasons. In both years, the NHI increased with plant population. It was comparatively stable in 1999/2000 with higher values than in the first year. Increased sowing depth increased the NHI by $4 \%$ (Table 5 ).

\section{Senesced leaves}

In both seasons the amount of senesced leaf increased as plant population increased. In 1998/99, senesced leaves increased as population density increased from one-tenth of the optimum to twice the optimum. However, further population increases did not affect the dry matter production of senesced leaves (Table 6). In $1999 / 2000$, senesced leaf TDM increased from 58 to $138 \mathrm{~g} / \mathrm{m}^{2}$ as plant population increased from 10 to 400 plants $/ \mathrm{m}^{2}$ (Table 6). In both seasons there were significant species by population interactions which showed that as population increased senesced leaf nitrogen increased for all species.

\section{Relationships between seed yield and TDM, and between seed $N$ and total plant $N$}

There was a significant linear relationship $(P<0 \cdot 001)$ between seed yield and TDM production at maturity 

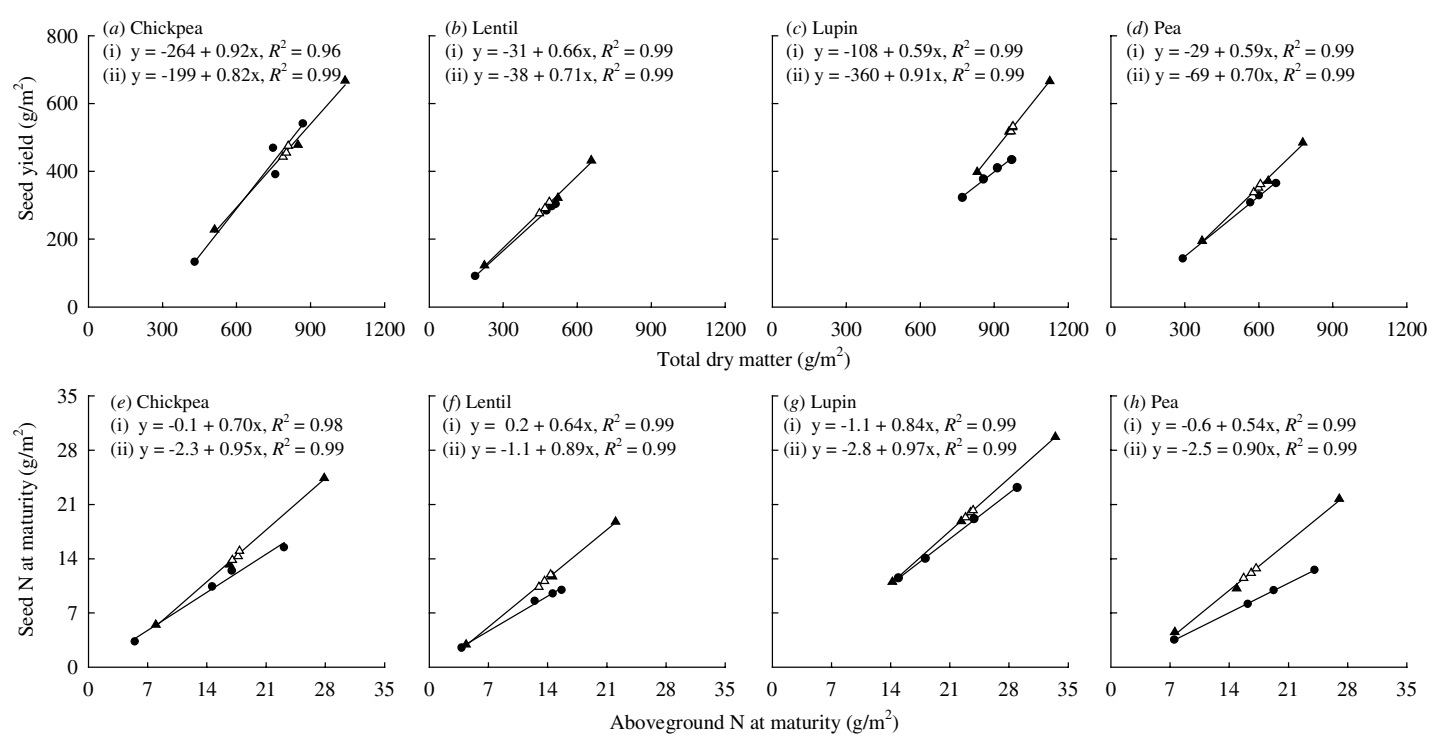

Fig. 3. The relationships between total dry matter and seed yield $(a-d)$ and seed nitrogen and above-ground nitrogen $(e-h)$ at final harvest of four grain legumes sown at four plant populations $(\boldsymbol{O})$ in 1998/99, and three plant populations $(\boldsymbol{\Delta})$ and three sowing depths $(\triangle)$ in $1999 / 2000$. The fitted equations are (i) $1998 / 99$ and (ii) $1999 / 2000$.

for each species $\left(R^{2}\right.$ of at least $\left.>0 \cdot 96\right)($ Fig. $3 a-d)$. Similarly, there was a significant linear $(P<0.001)$ relationship between seed $\mathrm{N}$ and net aboveground $\mathrm{N}$ (including senesced leaf $\mathrm{N}$ ) (Fig. $3 e-h)$. There were also positive correlations between NHI and the crop harvest index $(\mathrm{CHI})$. Both parameters were also positively correlated with seed yield and TDM (Table 7).

\section{DISCUSSION}

In the present study, plant $\mathrm{N}$ concentration varied among the four grain legumes and in their seed, straw and senesced leaves. This variation possibly indicates different rates of $\mathrm{N}$ translocation from vegetative parts to seed in the different species. Spaeth \& Sinclair (1983) considered that $\mathrm{N}$ accumulation in both seed and whole plants varied among soybean cultivars and indicated there were different rates of $\mathrm{N}$ translocation from vegetative tissues to seed.

The $\mathrm{N}$ concentration of legume species or their cultivars can be affected by symbiotic $\mathrm{N}$ fixation. This process ceases at leaf senescence, because of lack of assimilate supply to nodules, thus total plant $\mathrm{N}$ would stop increasing before final harvest while translocation of $\mathrm{N}$ to seed was still occurring (Newton \& Hill 1981). In all four species seed $\mathrm{N}$ concentration was higher than in the other plant parts. All four species had partitioned most of their $\mathrm{N}$ to seed by crop maturity. Burton et al. (1979) and Schulz et al. (1999) previously reported the highest proportion of $\mathrm{N}$ was located in seed in a range of grain legumes.
During the final stages of plant development, $\mathrm{N}$ moves from leaves, primarily to the seeds, at rates faster than it is deposited (Hanway 1976). This movement will be followed by reduced physiological activity and eventual leaf senescence and abscission (Burton et al. 1979).

The $\mathrm{N}$ concentration, averaged over both seasons, in senesced leaves was $26 \cdot 0,19 \cdot 3,16 \cdot 1$ and $11 \cdot 8 \mathrm{mg} / \mathrm{g}$ for field pea, chickpea, lentil and narrow-leafed lupin, respectively. Variation in $\mathrm{N}$ concentration in senesced mungbean cultivar leaves was $9 \cdot 4,11 \cdot 3$ and $14.3 \mathrm{mg} / \mathrm{g}$ for CPI 106032, Satin and ACC 41, respectively (Bushby \& Lawn 1992). Averaged over both seasons, the contribution of the $\mathrm{N}$ of the senesced leaves of the four legume species ranged from $20 \%$ in lupin to $35 \%$ in chickpea and pea of the total plant $\mathrm{N}$ (excluding root $\mathrm{N}$ ). This is clearly a substantial loss of nitrogen from the plant system. A loss of $\mathrm{N}$ with senescence was also reported in mungbean genotypes in Australia (Bushby \& Lawn 1992). The fraction of vegetative biomass and $\mathrm{N}$ partitioning to plant parts varies among legume species (Newton \& Hill 1981; Bushby \& Lawn 1992). Burton et al. (1979) reported in soybean, at maturity, $70 \%$ of the total $\mathrm{N}$ was in pods, $8 \%$ in straw and $22 \%$ in leaves.

The $\mathrm{N}$ yield of the seed of the different legumes ranked: narrow-leafed lupin $>$ chickpea $>$ field pea $>$ lentil. In straw it ranked: field pea $>$ narrow-leafed lupin > chickpea > lentil. Schulz et al. (1999) reported that faba bean had the highest $\mathrm{N}$ seed yield while Persian clover (Trifolium resupinatum), a pasture legume, had the highest straw $\mathrm{N}$ yield. 
Table 7. The correlation matrix between yield and nitrogen attributes in four grain legumes in Canterbury, $1998 / 99$ and $1999 / 2000$

\begin{tabular}{|c|c|c|c|c|c|c|}
\hline & SY & TDM & Total N & $E_{\mathrm{N}}$ & NHI & $\mathrm{CHI}$ \\
\hline Chickpea & & & & & & $1998 / 99$ \\
\hline SY & & 0.973 & 0.969 & 0.942 & 0.925 & 0.977 \\
\hline TDM & 0.987 & & 0.978 & 0.930 & 0.857 & 0.912 \\
\hline Total N & 0.916 & $0 \cdot 894$ & & 0.982 & 0.835 & 0.903 \\
\hline$E_{\mathrm{N}}$ & $0 \cdot 293$ & $0 \cdot 215^{*}$ & 0.611 & & $0 \cdot 804$ & $0 \cdot 888$ \\
\hline NHI & 0.666 & $0 \cdot 597$ & 0.772 & 0.722 & & 0.958 \\
\hline $\mathrm{CHI}$ & $\begin{array}{c}0.949 \\
1999 / 2000\end{array}$ & 0.901 & $0 \cdot 882$ & $0 \cdot 404$ & $0 \cdot 769$ & \\
\hline \multicolumn{7}{|l|}{ Lentil } \\
\hline SY & & 0.980 & 0.974 & 0.650 & 0.759 & 0.901 \\
\hline TDM & 0.997 & & 0.934 & 0.539 & $0 \cdot 664$ & $0 \cdot 800$ \\
\hline Total N & $0 \cdot 872$ & 0.865 & & 0.789 & 0.749 & 0.912 \\
\hline$E_{\mathrm{N}}$ & $0 \cdot 117^{\mathrm{ns}}$ & $0 \cdot 142^{\text {ns }}$ & $0 \cdot 326$ & & $0 \cdot 551$ & 0.779 \\
\hline NHI & $0 \cdot 385$ & $0 \cdot 359$ & 0.682 & $0 \cdot 823$ & & 0.839 \\
\hline $\mathrm{CHI}$ & $\begin{array}{c}0.919 \\
1999 / 2000\end{array}$ & 0.897 & $0 \cdot 851$ & $0 \cdot 094^{\mathrm{ns}}$ & $0 \cdot 556$ & \\
\hline \multicolumn{7}{|l|}{ Lupin } \\
\hline SY & & 0.919 & 0.708 & $0 \cdot 506$ & 0.619 & 0.630 \\
\hline TDM & 0.982 & & $0 \cdot 702$ & $0 \cdot 457$ & $0 \cdot 484$ & $0 \cdot 273^{\text {ns }}$ \\
\hline Total N & 0.828 & 0.827 & & 0.953 & $0 \cdot 701$ & $0 \cdot 346^{*}$ \\
\hline$E_{\mathrm{N}}$ & 0.597 & 0.579 & $0 \cdot 930$ & & 0.693 & $0 \cdot 338^{*}$ \\
\hline NHI & 0.626 & 0.567 & 0.854 & $0 \cdot 917$ & & 0.577 \\
\hline $\mathrm{CHI}$ & $\begin{array}{c}0.957 \\
1999 / 2000\end{array}$ & $0 \cdot 888$ & $0 \cdot 768$ & $0 \cdot 581$ & 0.669 & \\
\hline \multicolumn{7}{|l|}{ Pea } \\
\hline SY & & 0.983 & 0.920 & $0 \cdot 453$ & 0.633 & 0.644 \\
\hline TDM & 0.995 & & 0.946 & 0.469 & $0 \cdot 534$ & $0 \cdot 500$ \\
\hline Total N & 0.867 & $0 \cdot 857$ & & 0.715 & $0 \cdot 465$ & $0 \cdot 436$ \\
\hline$E_{\mathrm{N}}$ & $0 \cdot 418$ & $0 \cdot 401$ & 0.797 & & $0 \cdot 146^{\mathrm{ns}}$ & $0 \cdot 256^{\mathrm{ns}}$ \\
\hline NHI & 0.660 & 0.645 & 0.900 & 0.931 & & 0.747 \\
\hline $\mathrm{CHI}$ & $\begin{array}{c}0.943 \\
1999 / 2000\end{array}$ & 0.910 & 0.796 & $0 \cdot 360$ & 0.604 & \\
\hline
\end{tabular}

All values are highly significant $(P<0 \cdot 001)$, unless indicated as significant $*(P<0 \cdot 05)$ or ns $=$ not significant. SY $=$ seed yield, $\mathrm{TDM}=$ total dry matter, $\mathrm{CHI}=$ crop harvest index, $E_{\mathrm{N}}=$ nitrogen accumulation efficiency, $\mathrm{NHI}=$ nitrogen harvest index.

Narrow-leafed lupin was the most productive crop in terms of $\mathrm{N}$ yield and NHI (Tables 4 and 5). It contained more than $20 \mathrm{~g} \mathrm{~N} / \mathrm{m}^{2}$ in each season with the highest $\mathrm{N}$ content in the seed. Final seed $\mathrm{N}$ levels depend on the plant's ability to transfer $\mathrm{N}$ from vegetative tissues to the seed (Rattunde \& Frey 1986; Ganeshan et al. 1998).

Species which produced high seed yields such as Lupinus angustifolius also had high seed $\mathrm{N}$ yields. Hill et al. (1977) also reported that the seed $\mathrm{N}$ concentration of Lupinus angustifolius was higher than in pea. This may be due to narrow-leafed lupin being the most effective species in the Canterbury environment for biological N fixation (Rhodes 1980; Ganeshan et al. 1998). Schulz et al. (1999) reported that in Nepal, faba bean was the most effective crop in terms of biological $\mathrm{N}$ fixation and fixed more than $200 \mathrm{~kg}$ $\mathrm{N} /$ ha, but lentil performed poorly.

All four legumes had higher $N$ yields in 1999/2000 than in 1998/99. This was probably due to the higher rainfall in 1999/2000 (Fig. 1). Schulz et al. (1999) reported similar results. The high $\mathrm{N}$ yield may also have been due to the higher TDM yields in the second trial as total $\mathrm{N}$ yield is a function of per cent $\mathrm{N}$ and the DM yield per unit area (Rhodes 1980) and there was little variation in $\mathrm{N}$ concentration over the 2 years.

The amount of $\mathrm{N}$ in seed, as a proportion of total above-ground biomass $\mathrm{N}$ (the nitrogen harvest index, NHI) (Bushby \& Lawn 1992) was similar in chickpea, lentil and narrow-leafed lupin (mean of 0.79) in both seasons. However, NHI was lower in field pea $(0 \cdot 67)$. The high NHIs in the present study may have been due to the low non-seed $\mathrm{N}$ yields (Tables 4 and 5). Rhodes (1980) reported similar variation in the NHIs of pea and Lupinus angustifolius. The highest NHI was the result of less partitioning of $\mathrm{N}$ to stems and leaves of the narrow-leafed lupin. This suggests an efficient mobilization of $\mathrm{N}$ in straw and leaves to seed, particularly, in narrow-leafed lupin. Rhodes (1980) 
reported high NHIs of 0.86 and 0.91 for pea and lupin, respectively, and this was found to be due to the low $\mathrm{N}$ concentrations in the pod walls, stem and leaves. The results of Farrington et al. (1977) and Streeter (1978) with Lupinus angustifolius and soybean support this hypothesis. The low NHI of pea in the present study may have been due to crop lodging as lodging in wheat (Triticum aestivum) has been reported to inhibit $\mathrm{N}$ partitioning, which reduced the NHI by $30 \%$ (Canvin 1976).

Generally, NHI increased with increased plant population. This has also been reported in Vicia faba by Newton \& Hill (1981). This may have been due to a close relationship between the HI and the NHI (Table 7) as was also found in a range of grain legumes by Muchow et al. (1993b). A higher NHI may result from a greater depletion of the straw $\mathrm{N}$ reservoir. When this is combined with a greater proportion of seed in the plant more $\mathrm{N}$ is incorporated into the seed biomass (Löffler \& Busch 1982). More efficient partitioning of $\mathrm{N}$ to the seed without changing the amount of carbohydrate accumulated in the seed would increase seed protein concentration but would not greatly change HI (May et al. 1991).

In the present work, there were strong positive correlations between NHI and seed yield in all four legumes species as has been reported in wheat (Spratt \& Gasser 1970; Halloran 1981), oats (Avena sativa) (Rattunde \& Frey 1986) and cowpea, mung bean and soybean (Muchow et al. 1993 b). Therefore, selecting for a high NHI in grain legumes may also increase seed yield (Rattunde \& Frey 1986). Selection for NHI, in wheat, increased seed yield by 5 to $11 \%$ (Löffler \& Busch 1982).

In the present work the NHI and the CHI were positively correlated (Table 7) and both were positively correlated with seed yield. Similar results have been reported in cereals (Löffler \& Busch 1982; Rattunde \& Frey 1986). Thus, selection for both CHI and NHI may lead to increased seed yield in grain legumes. Since the determination of NHI is more laborious and costly than the measurement of $\mathrm{CHI}$, Löffler \& Busch (1982) and Rattunde \& Frey (1986) suggested that the close relationship between NHI and $\mathrm{CHI}$ may allow $\mathrm{CHI}$ to be used as an alternative selection criterion.

The nitrogen accumulation efficiency $\left(E_{\mathrm{N}}\right)$ at final harvest differed among legume species, plant population and sowing depths (Tables 4 and 5). Among the four legumes, chickpea had the lowest $E_{\mathrm{N}}(0 \cdot 018$ and $0.021 \mathrm{~g} \mathrm{~N} / \mathrm{g} \mathrm{DM}$ ). These values are similar to those of Chapman \& Muchow (1985), and Muchow et al. $(1993 b)$ for soybean, cowpea and mungbean in Australia. The ranking of the species for their $E_{\mathrm{N}}$ is the reverse of that for their RUE in the present study (Ayaz 2001). This negative association between $E_{\mathrm{N}}$ and RUE can possibly be explained by differences among the species in their use of photosynthate for $\mathrm{N}$ fixing symbiosis (Minchin et al. 1981). Lentil may have a high capacity $\mathrm{N}$ fixing system that gave a high $E_{\mathrm{N}}$, but a substantial proportion of photosynthate may have been used to support $\mathrm{N}$ fixation, with a concomitant reduction in DM production. This would give a lower conversion of intercepted radiation to DM. Similar results were reported for other grain legumes (Muchow et al. 1993 b).

Both sowing depth and population had small, variable but significant effects on the $E_{\mathrm{N}}$. The increase with increased sowing depth was probably due to greater moisture availability in the subsoil as reported for other grain legumes in Australia (Siddique \& Loss 1999). Chapman \& Muchow (1985) and de Vries et al. (1989) compared a range of grain legumes, and concluded that total $\mathrm{N}$ accumulated and estimated $E_{\mathrm{N}}$ generally decreased as water stress increased.

\section{CONCLUSIONS}

In spite of the wide variation in the degree of change in TDM and seed yield and $\mathrm{N}$ at final harvest, there were strong relationships between seed yield and total aboveground biomass at harvest maturity. Seed $\mathrm{N}$ and total aboveground $\mathrm{N}$ at final harvest were also strongly associated in all four legume species. The close correlations between NHI, CHI and seed yield mean that $\mathrm{CHI}$ can be used as a quick selection criterion for plant breeders searching for increased yield.

\section{REFERENCES}

AyAz, S. (2001). Variability of harvest index in four grain legume species. Ph.D. Thesis, Lincoln University, Canterbury.

Burton, J. W., Wilson, F. R. \& Brim, C. A. (1979). Dry matter and nitrogen accumulation in male-sterile and male-fertile soybeans. Agronomy Journal 71, 548-552.

Bushby, H. V. A. \& Lawn, R. J. (1992). Accumulation and partitioning of nitrogen and dry matter by contrasting genotypes of mungbean [Vigna radiata (L.) Wilczek]. Australian Journal of Agricultural Research 43, 1609-1628.
CAnvin, D. T. (1976). Interrelationship between carbohydrate and nitrogen metabolism. In Genetic Improvement of Seed Proteins, pp. 172-195. Washington, DC: National Academy of Sciences.

Chapman, A. L. \& Muchow, R. C. (1985). Nitrogen accumulated and partitioned at maturity by grain legumes grown under different water regimes in a semi-arid tropical environment. Field Crops Research 11, 69-79.

de Vries, J. D., Bennett, J. M., Boote, K. J., Albrecht, S. L. \& Maliro, C. E. (1989). Nitrogen accumulation and 
partitioning by three grain legumes in response to soil water deficits. Field Crops Research 22, 33-44.

Farrington, P., Greenwood, E. A. N., Titmanis, Z. V., Trinick, M. J. \& Smith, D. W. (1977). Fixation, accumulation and distribution of nitrogen in a crop of Lupinus angustifolius, cv. Unicrop. Australian Journal of Agricultural Research 28, 237-248.

Ganeshan, V., Hill, G. D. \& McKenzie, B. A. (1998). The dry matter yield of Italian ryegrass grown after grain legumes in a crop rotation. Proceedings of the Agronomy Society of New Zealand 28, 87-94.

Halloran, G. M. (1981). Cultivar differences in nitrogen translocation in wheat. Australian Journal of Agricultural Research 32, 535-544.

HANWAY, J. J. (1976). Interrelated developmental and biochemical processes in the growth of soybean plants. In World Soybean Research (Ed. L. D. Hill). Danville, Illinois: The Interstate Printers and Publishers, Inc.

Hewitt, A. E. (1992). New Zealand soil classification. DSIR Land Resources Scientific Report No. 19. Lower Hutt: DSIR.

Hill, G. D., Horn, P. E. \& Porter, N. G. (1977). A comparison of seed and nutrient yield of spring-sown grain legumes. Proceedings of the Agronomy Society of New Zealand 7, 65-68.

LöfFler, C. M. \& BusCh, R. H. (1982). Selection for grain protein, grain yield and nitrogen partitioning efficiency in hard red spring wheat. Crop Science 22, 591-595.

May, L., van SAnford, D. A., MacKown, C. T. \& Cornelius, P. L. (1991). Genetic variation for nitrogen use in soft red $\times$ hard red winter wheat populations. Crop Science 31, 626-630.

Minchin, F. R., Summerfield, R. J., Hadley, P. \& Rawsthorne, S. (1981). Carbon and nitrogen nutrition of nodulated roots of grain legumes. Plant Cell Environment 4, 5-26.

Muchow, R. C., Robertson, M. J. \& Pengelly, B. C. $(1993 a)$. Radiation use efficiency of soybean, mungbean and cowpea under different environmental conditions. Field Crops Research 32, 1-16.

Muchow, R. C., Robertson, M.J. \& Pengelly, B. C. $(1993 b)$. Accumulation and partitioning of biomass and nitrogen by soybean, mungbean and cowpea under contrasting environmental conditions. Field Crops Research 33, 13-36.

Newton, S. D. \& Hill, G. D. (1981). Nitrogen studies in autumn and spring sown field beans (Vicia faba L.). Proceedings of the Agronomy Society of New Zealand 11, $11-16$.

Rattunde, H. F. \& Frey, K. J. (1986). Nitrogen harvest index in oats: its repeatability and association with adaptation. Crop Science 26, 606-610.

Rhodes, P. J. (1980). Nitrogen fixation by pea and lupin. MAgrSc Thesis, Lincoln College, University of Canterbury.

Schulz, S., Keatinge, J. D. H. \& Wells, G. J. (1999). Productivity and residual effects of legumes in rice-based cropping systems in a warm-temperate environment. I. Legume biomass production and $\mathrm{N}$ fixation. Field Crops Research 61, 23-35.

Siddique, K. H. M. \& Loss, S. P. (1999). Studies on sowing depth for chickpea (Cicer arietinum L.), faba bean (Vicia faba L.) and lentil (Lens culinaris Medik), in a Mediterranean-type environment of south-western Australia. Journal Agronomy and Crop Science 182, 105-112.

Spaeth, S. C. \& Sinclair, T. R. (1983). Variation in nitrogen accumulation and distribution among soybean cultivars. Field Crops Research 7, 1-12.

Spratt, E. D. \& Gasser, J. K. R. (1970). Effects of fertilizer-nitrogen and water supply on distribution of dry matter and nitrogen between different parts of wheat. Canadian Journal of Plant Science 50, 613-625.

Streeter, J. G. (1978). Effects of N starvation of soybean plants at various stages of growth on seed yield and $\mathrm{N}$ concentration of plant parts at maturity. Agronomy Journal 70, 74-76. 